\title{
PARTISIPASI MASYARAKAT DALAM PENGELOLAAN SAMPAH DI LINGKUNGAN MARGALUYU KELURAHAN CICURUG
}

\author{
Oleh: \\ Nur Rahmawati Sulistiyorini, Rudi Saprudin Darwis, \& Arie Surya Gutama \\ E-mail: tiarahmawati10@gmail.com
}

\begin{abstract}
ABSTRAK Produksi sampah setiap hari semakin meningkat seiring dengan bertambahnya jumlah produk dan pola konsumsi masyarakat. Hal yang harus dilakukan untuk mengatasi paningkatan volume sampah tersebut adalah dengan cara: mengurangi volume sampah dari sumbernya melalui pemberdayaan masyarakat. Permasalahan dalam partispasi masyarakat mengenai pengelolaan sampah adalah apa saja bentuk regulasi yang terkait dengan pengelolaan sampah di Lingkungan Margaluyu, bagaimanakah bentuk partisipasi masyarakat dalam pengelolaan sampah dan tngkat partisipasi masyarakat dalam pengelolaan sampah. Penelitian tentang pengelolaan sampah berbasis partisipasi masyarakat di Lingkungan Margaluyu Kelurahan Cicurug, Tujuan untuk: (1) mendeskripsikan bentuk partisipasi masyarakat di Lingkungan Margaluyu. (2) mendeskripsikan tingkat partisipasi masyrakat di Lingkungan Margaluyu Teknik pengumpulan data meliputi wawancara, observasi dan dokumentasi, sedangkan analisis data menggunakan teknik deskriptif kualitatif. Berdasarkan hasil penelitian, salah satu bentuk peran serta masyarakat dalam upaya perbaikan lingkungan yaitu dengan memberikan sumbangan tenaga berupa kerja bakti dan ikut serta dalam pengelolaan sampah. Selain itu, mereka juga mengadakan pertemuan warga yang dilakukan satu kali dalam sebulan, yang dihadiri oleh sebagian warga untuk tingkat RW dan seluruh warga untuk tingkat RT. Dalam hal ini tingkat RT cenderung berbentuk partisipasi langsung sedangkan tingkat RW berbentuk partisipasi tak langsung. Warga melakukan kegiatan tersebut tanpa merasa terpaksa sama sekali. Tingkat peran serta masyarakat yang terjadi di Lingkungan Margaluyu Kelurahan Cicurug menurut kategori sedang, masyarakat ikut serta partisipasi akan tetapi pelaksanaanya masih belum maksimal.
\end{abstract}

Kata Kunci : Partisipasi masyarakat, dalam pengelolaan sampah.

ABSTRAC Production of waste every day is increasing as the number of products and patterns of consumption. The thing to do to overcome is that the increase in the volume of waste by means of: reducing the volume of waste from the source through community empowerment. Problems in public participation regarding waste management is any form of regulation related to waste management in the Environment Margaluyu, what form of community participation in waste management and tngkat community participation in waste management. Research on community-based waste management in the Environment Village Margaluyu Cicurug, Goals for: (1) describe the form of community participation in the Environment Margaluyu. (2) describe the level of participation of the community in Margaluyu Environmental Engineering Data collection includes interviews, observation and documentation, while the analysis of data using qualitative descriptive technique. Based on this research, one of the forms of community participation in environmental improvement efforts is by donating labor in the form of voluntary work and participate in waste management. In addition, they also held a community meeting is held once in a month, which was attended by some residents to level entire neighborhoods and residents to the neighborhood level. In this case the 
neighborhood level tend to be shaped while the direct participation of the local level in the form of indirect participation. Residents perform these activities without feeling forced at all. The level of community participation that occurred in the village of Environmental Margaluyu Cicurug according to the category of being, society will participate participation but its implementation is still not maximal.

Key Words : Community participation, in waste management.

\section{PENDAHULUAN}

Untuk mencapai kondisi masyarakat yang hidup sehat dan sejahtera di masa yang akan datang, akan sangat diperlukan adanya lingkungan permukiman yang sehat. Dari aspek persampahan, maka kata sehat akan berarti sebagai kondisi yang akan dapat dicapai bila sampah dapat dikelola secara baik sehingga bersih dari lingkungan permukiman dimana manusia beraktifitas di dalamnya. Persoalan lingkungan yang selalu menjadi isu besar di hampir seluruh wilayah perkotaan adalah masalah sampah (Febrianie dalam Kompas 10 Januari 2004). Arif Rahmanullah dalam Kompas, 13 Agustus 2003 mengatakan bahwa laju pertumbuhan ekonomi di kota dimungkinkan menjadi daya tarik luar biasa bagi penduduk untuk hijrah ke kota (urbanisasi). Akibatnya jumlah penduduk semakin membengkak, konsumsi masyarakat perkotaan melonjak, yang pada akhirnya akan mengakibatkan jumlah sampah juga meningkat.

Pertambahan jumlah sampah yang tidak diimbangi dengan pengelolaan yang ramah lingkungan akan menyebabkan terjadinya perusakan dan pencemaran lingkungan (Tuti Kustiah, 2005:1). Lebih jauh lagi, penanganan sampah yang tidak komprehensif akan memicu terjadinya masalah sosial, seperti amuk massa, bentrok antar warga, pemblokiran fasilitas TPA. Pertumbuhan jumlah sampah di kota-kota di Indonesia setiap tahun meningkat secara tajam. Sebagai contoh di Kota Bandung. Di kota ini, pada tahun 2005 volume sampahnya sebanyak $7.400 \mathrm{~m} 3$ per hari; dan pada tahun 2006 telah mencapai $7.900 \mathrm{~m} 3$ per hari. Selain itu, di Jakarta, pada tahun 2005 volume sampah yang dihasilkan sebanyak $25.659 \mathrm{~m} 3 /$ hari; dan pada tahun 2006 telah mencapai 26,880 m3/hari. (Suganda dalam Kompas, 30 Nopember 2006).

Sampah sangat berbahaya bagi kesehatan manusia dan lingkungan sekitar. Oleh karena itu, sampah haruslah diolah atau di daur ulang dengan baik agar tidak mencemari lingkungan dan mengganggu kesehatan manusia. Sampah yang selama ini kita buang begitu saja, ternyata masih dapat diolah kembali antara lain dalam bentuk kerajinan yang bernilai ekonomi, bercita rasa seni dan unik. Secara umum pengelolaan sampah dilakukan dalam tiga tahap kegiatan, yaitu : pengumpulan, pengangkutan, dan pembuangan akhir/pengolahan. Pada tahap pembuangan akhir/pengolahan, sampah akan mengalami proses-proses tertentu, baik secara fisik, kimiawi, maupun biologis.

Partisipasi masyarakat dalam pengelolaan sampah dapat meningkatkan kesadaran masyarakat akan pentingnya kebersihan lingkungan yang hijau, bersih dan sehat serta menguatkan inisiatif masyarakat dalam menjaga, memelihara dan meningkatkan fungsi lingkungan. Disamping itu, kemampuan masyarakat berkontribusi dalam pengelolaan sampah juga akan sangat tergantung kepada pendapatan masyarakat, khususnya di lingkungan Margaluyu, Kabupaten Majalengka. Kondisi keadaan Kelurahan Cicurug adalah merupakan bagian dari Kabupaten Majalengka yang posisi lokasinya terletak di kecamatan Majalengkayaitu perbatasan sebelah barat dengan kelurahan Babakan jawa, sebelah utara dengan Kelurahan Majalengka Wetan, sebelah selatan dengan kelurahan Sindangkasih dan sebelah timur dengan kecamatan Cigasong 
kondisi alam yang sejuk diapit dengan pegunungan yang asri. Luas wilayah + 129,725 HA m2, adapun jarak tempuh ke kota kecamatan adalah 1,5 KM dan jarak tempuh ke ibukota kabupaten $+2,5 \mathrm{~km}$ berpenduduk 2381 KK ( 8187 Jiwa ). Pria sebanyak 4206 Jiwa dan wanita sebanyak 3981 jiwaterbagi menjadi 9( RW ) dan 27 RT. (Sumber : Profil Kantor Kelurahan Cicurug Kabupaten Majalengka, 2015).

Partisipasi masyarakat di Lingkungan Margaluyu dalam pengelolaan sampah di Lingkungan ini yang awalnya masyarakat sangat acuh dengan keberadaan sampah dengan adanya program pengelolaan sampah masyarakat mulai sadar dengan sampah dan memulai untuk mengelolanya. Saat ini di Lingkungan Magaluyu Kelurahan Cicurug Kecamatan/ Kabupaten Majalengka pengelolaan sampah sudah dilakukan secara tepadu yang dilakukan oleh Kelompok Swadaya Masyarakat (KSM) Hanjuang-Saung Eurih.KSM Hanjuang-Saung Eurih (Sumber : Informan Masyarakat, tahun 2015). Partisipasi dari berbagai pihak merupakan salah satu kunci keberhasilan suatu kegiatan ataupun program. Menurut Sumardi dan Evers (1982, 3) partisipasi adalah ikut sertanya suatu kesatuan untuk mengambil bagian dalam aktivitas yang dilaksanakan oleh susunan kesatuan yang lebih besar dari masyarakat dapat diartikan sebagai keikutsertaan masyarakat dalam suatu kegiatan bersama sesuai dengan kemampuannya masing-masing untuk menunjang pencapaian tujuan tertentu tanpa mengorbankan kepentingan diri sendiri. Lebih dari itu, partisipasi berkaitan dengan tiga hal yakni mental and emotional involvement (keterlibatan mental dan emosi), motivation to contribute (dorongan untuk memberikan sumbangan), dan acceptance of responsibility (penerimaan tanggung jawab) sebagaimana diungkapkan (Davis Hurairah, Jurnal Sosial, 2012).

Kelurahan Cicurug Kecamatan Majalengka merupakan daerah yang memiliki jumlah penduduk 6.508 Jiwa yang mana memiliki kontribusi terhadap penambahan jumlah sampah di Kabupaten Majalengka, terlebih tidak adanya tempat pembuangan sampah sementara sehingga tanpa adanya pengarahan dari Pihak manapun masyarakat melakukan pembuangan sampah dengan pola Open Dumping serta membuang sampah ke sungai. Kebiasaan buruk masyarakat tersebut memiliki dampak negative terhadap lingkungan dan sungai, yang membuat terjadinya longsoran tanah di sisi sungai dikarenakan dijadikan lahan Open Dumping oleh masyarakat, dan dikhawatirkan jika masalah ini akan semakin buruk dari tahun ketahun. Untuk menjaga kelestarian lingkungan di sekitar kita maka masyarakat yang ada di kelurahan Cicurug harus terlibat dalam pengelolaan sampah mulai dari rumah tangga.

Untuk mengetahui tingkat partisipasi masyarakat dalam pengelolaan sampah di wilayah tersebut, maka perlu di lakukan penelitian secara mendalam, dengan alasan bahwa masalah sampah yang saat ini semakin santer di masyarakat yang merupakan salah satu masalah sosial. Masalah partisipasi masyarakat merupakan bidang kajian praktek pekerjaan sosial atau sangat relevan dengan fungsi dan tugas pekerjaan soial dalam memberikan intervensi pada pertolongan individu, kelompok, dan masyarakat yang mengalami masalah sosial.

\section{Metode Penulisan}

Metode yang digunakan dalam penulisan karya tulis ilmiah ini adalah metode penelitian deskriptif.Metode yang digunakan untuk mengumpulkan data adalah metode studi pustaka yang terdiri atas pencarian data dan informasi melalui dokumen-dokumen pendukung berupa data dari buku, jurnal ilmiah, dan dokumen elektronik dari internet. Adapun tahapan dalam penulisan diantaranya perumusan masalah untuk kemudian menjadi gagasan, pengumpulan data dan fakta terkait, verifikasi data dan fakta, analisa konseptual dengan argumentasi yang rasional, perumusan hasil gagasan dan kesimpulan serta rekomendasi terkait penanganan masalah. 
Telaah Pustaka

Partisipasi Masyarakat

Partisipasi dapat diartikan dengan keikutsertaan atau keterlibatan baik secara fisik maupun non fisik dari seorang individu atau masyarakat. Pernyataan tersebut sesuai dengan pendapat Santosa (1998:13) bahwa :

"Partisipasi didefinisikan sebagai karakteristik mental/pikiran dan emosi/perasaan seseorang dalam situasi kelompok yang mendorongnya untuk memberikan sumbangan kepada kelompok dalam usaha mencapai tujuan serta turut bertanggung jawab terhadap usaha yang bersangkutan."

Definisi tersebut menekankan bahwa partisipasi merupakan suatu alat untuk mencapai tujuan yang telah ditetapkan, serta lebih menekankan pada aspek psikologis yang mendorong seseorang atau individu untuk melakukan tindakan tertentu dalam rangka mencapai tujuan. Berdasarkan pengertian tersebut, maka terdapat tiga unsur partisipasi, yaitu :

\section{Adanya tanggung jawab}

2. Kesediaan memberikan sumbangan untuk mencapai tujuan kelompok

3. Kesediaan mereka terlibat di dalam kelompok

Dari definisi-definisi tentang partisipasi yang dikemukakan oleh para ahli tersebut dapat disimpulkan bahwa partisipasi masyarakat dalam pengelolaan sampah pada dasarnya merupakan keterlibatan aktif masyarakat dalam proses pembuangan, pengangkutan, dan pengelolaan sampah, atas dasar rasa kesadaran dan tanggung jawab untuk mencapai tujuan bersama mewujudkan lingkungan yang bersih dan sehat. Sesuai dengan pernyataan Sastropoetro (1988:37), bahwa "Keterlibatan Spontan dengan kesadaran disertai tanggung jawab terhadap kepentingan kelompok untuk mencapai tujuan".

Berdasarkan pendapat tersebut, maka partisipasi seseorang sebaiknya didasarkan atas kesadaran sendiri, keyakinan serta kemauan, sebab hal itu akan bermanfaat bagi dirinya. Karena dirinya merasa tidak dipaksakan sehingga dalam mengikuti kegiatan dapat dilaksanakan dengan sukarela.

\section{Jenis-Jenis Partisipasi Masyarakat}

Tidak semua partisipasi ada atas kesadaran dan inisiatif warga masyarakat tetapi juga bisa merupakan mobilisasi dari atas untuk mencapai tujuan. Menurut Uphoff, Cohen, dan Goldsmith (1979: 51) membagi partisipasi ke dalam beberapa tahapan, yaitu:

1. Tahap perencanaan, ditandai dengan keterlibatan masyarakat dalam kegiatankegiatan yang merencanakan program pembangunan yang akan dilaksanakan, serta menyusun rencana kerjanya.

2. Tahap pelaksanaan, yang merupakan tahap terpenting dalam program, inti dari keberhasilan suatu program adalah pelaksanaan. Wujud nyata partisipasi pada tahap ini dapat digolongkan menjadi tiga, yaitu partisipasi dalam bentuk sumbangan pemikirn, bentuk sumbangan materi, dan bentu keterlibatan sebagai anggota.

3. Tahap menikmati hasil, yang dapat dijadikan indicator keberhasilan partisipasi masyarakat pada tahap perencanaan dan pelaksanaan program.

4. Tahap evaluasi, dianggap penting sebab partisipasi masyarakat pada tahap ini dianggap sebagai umpan balik yang dapat memberi masukan demi perbaikan pelaksanaan program.

Menurut Sastropoetro (1986: 16-18) jenis partisipasi meliputi (1) Pemikiran; (2) Tenaga; (3) Pemikiran dan Tenaga; (4) Keahlian; (5) Barang; (6) Uang. Kemudian Hamijoyo (2007: 21) menjabarkan jenis partisipasi sebagai berikut:

1. Partisipasi pemikiran adalah partisipasi berupa sumbangan ide, pendapat atau buah pikiran konstruktif, baik untuk menyusun program, maupun untuk memperlancar 
pelaksanaan program dan juga untuk mewujudkannya dengan memberikan pengalaman dan pengetahuan guna mengembangkan kegiatan yang diikutinya.

2. Partispasi tenaga adalah partisipasi yang diberikan dalam bentuk tenaga untuk pelaksanaan usaha-usaha yang dapat menunjang keberhasilan suatu program.

3. Partisipasi ketrampilan adalah memberikan dorongan melalui ketrampilan yang dimilikinya kepada anggota masyarakat lain yang membutuhkannya. Dengan maksud agar orang tersebut dapat melakukan kegiatan yang dapat meingkatkan kesejahteraan sosialnya.

4. Partisipasi barang adalah partisipasi dalam bentuk menyumbang barang atau harta benda, biasanya berupa alat-alat kerja.

5. Partisipasi uang adalah bentuk partisipasi untuk memperlancar usaha-usaha bagi pencapaian kebutuhan masyarakat yang memerlukan bantuan.

\section{Tingkat Partisipasi Masyarakat}

Partisipasi itu berproses dan untuk membedakan prosesnya dibuatlah tangga/tingkatan partisipasi. Teori tingkat partisipasi ini digunakan sebagai dasar untuk melakukan pembobotan terhadap tolok ukur tingkat partisipasi masyarakat. Konsep tingkat partisipasi dari berbagai teori dan pengalaman dalam bidang perencanaan partisipatif. Tingkatan Partisipasi menurut Hetifah $\mathrm{Sj}$. Sumarto. Pendapat yang diutarakan oleh salah seorang praktisi lapangan dalam bidang perencanaan partisipatif di Indonesia yaitu Sumarto (2003:113). Melihat dari pengalaman praktis dari perencanaan partisipatif di beberapa kawasan Indonesia, Sumarto mengelompokkan tingkat partisipasi masyarakar menjadi 3 bagian yaitu:

1. Tinggi

- Inisiatif datang dari masyarakat dan dilakukan secara mandiri mulai dari tahapan perencanaan, pelaksanaan hingga pemeliharaan hasil pembangunan.

- Masyarakat tidak hanya ikut merumuskan program, akan tetapi juga menentukan program-program yang akan dilaksanakan

2. Sedang

- Masyarakat sudah ikut berpartisipasi, akan tetapi dalam pelaksanaannya masih didominasi golongan tertentu

- Masyarakat dapat menyuarakan aspirasinya, akan tetapi masih terbatas pada masalah keseharian

3. Rendah

- Masyarakat hanya menyaksikan kegiatan proyek yang dilakukan oleh pemerintah.

- Masyarakat dapat memberikan masukan baik secara langsung atau melalui media massa, akan tetapi hanya sebagai bahan pertimbangan saja.

- Masyarakat masih sangat bergantung kepada dana dari pihak lain sehingga apabila dana berhenti maka kegiatan secara stimulan akan terhenti juga.

Tinjauan tentang Sampah

Menurut Davis dan Cornwell (2008: 737) menjelaskan bahwa kata sampah padat merupakan suatu kata yang umum digunakan untuk menggambarkan sesuatu yang kita buang. Sampah padat, dimana terdiri dari bermacam benda-benda yang sudah dibuang, mengandung berbagai macam zar baik yang dapat berbahaya maupun tidak bebahaya. Akan tetapi secara umum, sampah padat yang menumpuk mampu menimbulkan dampak yang cukup serius bagi populasi manusia yang padat. Dari penjelasan tersebut, masalah sampah sebagai salah satu permasalahan lingkungan dapat dikatakan juga sebagai masalah sosial yang perlu diatur karena mempengaruhi kehidupan masyarakatl luas sebagaimana dikatakan bahwa lingkungan 
merupakan factor pendukung kehidupan manusia.

Salah satu upaya untuk dapat menyelesaikan permasalahan sampah adalah dengan melakukan pengelolaan sampah yang bisa dilakukan dengan prinsip $3 \mathrm{R}$ (reduce, reuse, dan recycle). $3 \mathrm{R}$ adalah prinsip utama mengelola sampah mulai dari sumbernya, melalui berbagai langkah yang mampu mengurangi jumlah sampah yang dibuang ke TPA (Tempat Pembuangan Akhir). Langkah utama adalah penilihan sejak dari sumber. Menurut Enviromental Services Program (2011: 19) kunci keberhasilan program kebersihan dan pengelolaan sampah terletak pada pemilihan. Tanpa pemilihan pengolahan sampah menjadi sulit, mahal dan beresiko tinggi mencemari lingkungan dan membahayakan kesehatan. Pemilihan adalah memisahkan antara jenis sampah yang satu dengan jenis yang lainnya. Minimal pemilihan menjadi dua jenis:

a. Sampah organik, yaitu sampah yang tidak dapat di daur ulangyang dapat dirubah menjadi kompos yang bernilai seperti sayur, buah-buahan, dan sebagainya.

b. Sampah non-organik, yaitu sampah yang dapat di daur ulang menjadi benda/barang lain yang dapat bermanfaat kembali seperti plastik, kaca, logam, dan sebagainya.

Tinjauan Tentang Pengelolaan Sampah

Sampah harus dikelola secara baik sampai sekecil mungkin agar tidak menganggu dan mengancam kesehatan masyarakat. Pengelolaan sampah yang baik, bukan untuk kepentingan kesehatan saja, tetapi juga untuk keindahan lingkungan. Pengelolaan sampah meliputi pengumpulan, pengangkutan, sampai dengan pemusnahan atau pengelolaan sampah sedemikian rupa sehingga sampah tidak menganggu kesehatan masyarakat dan lingkungan hidup. Cara pengelolaan sampah antara lain:

a. Pengumpulan dan pengangkutan sampah
Pengumpulan sampah adalah menjadi tanggung jawab dari masing-masing rumah tangga atau industri yang menghasilkan sampah. Oleh karena itu, mereka harus membangun atau mengadakan tempat khusus kemudian dari masing-masing tempat pengumpulan sampah tersebut harus diangkut ke tempat penampungan sampah (TPS) dan selanjutnya ke tempat penampungan akhir (TPA). Mekanisme sistem atau cara pengangkutan untuk di derah perkotaan adalah tanggung jawab pemerintah daerah setempat yang didukung oleh partisipasi masyarakat produksi sampah, khususnya dalam hal pendanaan. Sedangkan untuk daerah pedesaan pada umumnya dapat dikelola oleh masingmasing keluarga, tanpa memerluka TPS maupun TPA. Sampah rumah tangga daerah pedesaan umumnya didaur ulang menjadi pupuk.

b. Pemusnahan dan pengelolaan sampah

Pemusnahan dan atau pengelolaan sampah padat ini dapat dilakukan melalui berbagai cara, antara lain:

- Ditanam (landfill), yaitu pemusnahan sampah dengan membuat ladang di tanah kemudian sampah dimasukkan dan ditimbun dengan tanah.

- Dibakar (inceneration), yaitu memusnahkan sampah dengan jalan membakar di dalam tungku pembakaran (incenerator).

- Dijadikan pupuk (composting), yaitu pengolahan sampah menjadi pupuk (kompos) khususnya untuk sampah organik daun-daunan, sisa makanan, dan sampah lain yang dapat membusuk. Di daerah pedesaan hal ini sudah biasa, sedangkan di daerah perkotaan hal ini perlu dibudayakan. Apabila setiap rumah tangga dibiasakan untuk memisahkan sampah organik dengan an-organik, kemudian sampah organik diolah menjadi pupuk tanaman dapat dijual atau dipakai sendiri. Sedangkan sampah an-organik dibuang dan akan segera dipungut oleh 
pemulung. Dengan demikian maka masalah sampah akan berkurang.

- Penghancuran (pulverization); Beberapa kota besar di Indonesia telah memiliki mobil pengumpul sampah yang dilengkapi alat pelumat sampah. Sampah yang berasal dari bak-bak penampungan langsung dihancurkan menjadi potongan-potongan kecil sehingga lebih ringkas. Sampah yang telah dilumatkan dapat dimanfaatkan untuk menimpun permukaan tanah yang rendah. Selain itu juga bisa dibuang ke laut tanpa menimbulkan pencemaran.

- Makanan ternak (hogfeeding), Sampah organik seperti sayuran, ampas tapioka, dan ampas tahu dapat dimanfaatkan sebagai makanan ternak.

- Pemanfaatan ulang (recycling); Sampah-sampah yang sekiranya masih bisa diolah, dipungut, dan dikumpulkan. Contohnya adalah kertas, pecahan kasa, botol bekas, logam, dan plastik. Sampah-sampah semacam ini dapat dibuat kembali menjadi karton, kardus pembungkus, alat-alat perangkat rumah tangga dari plastik dan kaca. Tetapi perlu diingat jangan sampai sampah demikian dimanfaatkan atau termanfaatkan lagi. Misalnya, kertas-kertas dari tempat sampah dimanfaatkan begitu saja untuk membungkus kudapan atau makanan. Hal ini membahayakan bagi kesehatan.

- Pengelolaan sampah yang baik dan layak bukan saja dapat meninggalkan kebersihan maupun estetika lingkungan, akan tetapi juga dapat meniadakan atau menghambat berkembang biaknya vektor berbagai penyakit menular yang dapat merugikan kesehatan masyarakat. Hal tersebut dikarenakan sampah dapat sebagai sumber makanan, sarang/tempat tinggal serta media yang baik untuk perkembangan kehidupan makhluk hidup.

\section{Community Development}

Konsep pengembangan masyarakat (Community Development) sebenarnya adalah pengorganisasian Masyarakat (Community Organization), yang bermakna mengorganisasikan masyarakat sebagai sebuah sistem untuk melayani warganya dalam setting kondisi yang berubah. Dengan demikian inti pengertiannya adalah mendorong warga masyarakat untuk mengorganisasikan diri untuk melaksanakan kegiatan guna mencapai kesejahteraannya sendiri. (Budhi Wibhawa dkk, Dasar-dasar Pekerjaan Sosial, 2010:109)

PBB (1995) mendefinisikan pengembangan masyarakat sebagai berikut:

"Pengembangan masyarakat didefinisikan sebagai suatu proses yang dirancang untuk menciptakan kemajuan kondisi ekonomi dan sosial bagi seluruh warga masyarakat dengan partisipasi aktif dan sejauh mungkin menumbuhkan prakarsa masyarakat itu sendiri”.

Dari pengertian tersebut dapat dikatakan bahwa pengembangan masyarakat sejatinya merupakan bentuk intervensi pekerjaan sosial yang bertujuan untuk memberikan perubahan terhadap masyarakat dari segala aspek kehidupan, baik itu sosial, ekonomi, dan aspek kehidupan yang lainnya.

Pengembangan masyarakat (Community Development) menurut Jim Ife dan Longman (1995) merupakan konsep yang berkembang sebagai tandingan terhadap konsep Negara kesejahteraan. Jim Ife dan Logman menyebutkan bahwa:

"Konsep pengembangan masyarakat lebih menekankanpada upaya pemenuhan kebutuhan yang dilakukan oleh masyarakat sendiri (community based services) dengan ide utama keberlanjutan dalam penyelenggaraan kebutuhan hidup manusia karena dikembangkannya keswadayaan (self 
reliance). Pengembangan masyarakat harus selalu mencaru cara untuk menumbuhkan dan memaksimalkan partisipasi, dengan maksud agar setiap warga masyarakat terlibat secara aktif dalam proses dan aktivitas kemasyarakatan untuk mencapai tujuan bersama"

Dalam pekerja sosial pengembangan masyarakat adalah metode yang bertujuan untuk memperbaiki kualitas hidup masyarakat melalui penggunaan sumber-sumber yang ada pada mereka serta menekankan pada partisipasi sosial (Suharto, 2009: 37). Pengembangan masyarakat diselenggarakan dengan tujuan untuk mencapai kondisi masyarakat dimana transformasi sosialbudaya, politik, ekonomi, teknologi, dapat dilaksanakan oleh masyarakat secara berkelanjutan. Ada tiga karakter umum program pengembangan mayarakat, yaitu:

1. Berbasis masyarakat (community-base) atau masyarakat sebagai pelaku utama atau subyek dalam perencanaan dan pelaksanaan program

2. Berbasis sumberdaya setempat (local resources-base), yaitu penciptaan kegiatan dengan melihat potensi sumberdaya (alam, manusia) yang ada.

3. Berkelanjutan (sustainable) yaitu program berfungsi sebagai penggerak awal pembangunan yang berkelanjutan.

Pengembangan masyarakat memiliki fokus terhadap upaya menolong anggota masyarakat yang memiliki kesamaan minat untuk bekerja sama, mengidentifikasi kebutuhan bersama dan kemudian melakukan kegiatan bersama untuk memenuhi kebutuhan tersebut. Pengembangan masyarakat seringkali diimplementasikan dalam bentuk:

a. Proyek-proyek pembangunan yang memungkinkan anggota masyarakat memperoleh dukungan dalam memenuhi kebutuhannya atau melalui

b. Kampanye dan aksi sosial yang memungkinkan kebutuhan-kebutuhan tersebut dapat dipenuhi oleh pihak-pihak lain yang bertanggung jawab (Payne, 1995:165).

Menurut Jim Ife (1995: 178-198), prinsip dasar dalam Community Development yang harus diperhatikan adalah pengembangan terintegrasi, hak asasi manusia, berkelanjutan, pemberdayaan, kemandirian, pengembangan organisasi, integritas proses, kooperatif, partisipasi, melawan penindasan struktural, konsensus personal dan politik, hak milik masyarakat, tidak bergantung pada Negara, tujuan jangka pendek dan visi akhir, langkahlangkah pengembangan, keahlian eksternal membangun masyarakat, tanpa kekerasan, keikutsertaan dan mendefinisikan kebutuhan.

Relevansi pekerjaan sosial dalam pengelolaan sampah, didasarkan pada kompetensi pekerjaan sosial yaitu pada bidang kesejahteraan sosial, dimana profesi pekerjaan sosial memiliki peranan dominan dalam pembangunan kesejahteraan sosial. Pekerjaan sosial merupakan profesi pertolongan yang ditujukkan untuk mendorong pemecahan masalah, baik individu, keluarga, dan masyarakat dengan berusaha membantu menggunakan kemampuan untuk menghadapi masalah-masalah sosial dalam kehidupan sehari-hari secara aktif dan bertanggung jawab. Aktif dan tanggung jawab disini merupakan pendekatan pelayanan dengan pengakuan terhadap kemampuan yang dimiliki oleh individu, kelompok ataupun masyarakat dalam kata lain selain dibantu juga ikut berpartisipasi dalam pemecahan masalahnya. Partisipasi sejalan dengan prinsip pekerjan sosial yaitu "self determination" (memiliki hak untuk menentukkan dirinya sendiri). Artinya bahwa seorang pekerja sosial berupaya melibatkan individu, kelompok, ataupun masyarakat dengan mendayagunakan kemampuan yang dimiliki.

Dengan demikian dapat dikatakan bahwa fokus intervensi pekerjaan sosial dalam pengelolaan sampah adalah menggunakan locality development, Locality development adalah proses yang ditujukan untuk menciptakan kemajuan sosial dan ekonomi bagi masyarakat melalui partisipasi aktif serta 
inisiatif anggota masyarakat itu sendiri (United Nations, 1955). Dalam pengelolaan sampah ini pekerja sosial masuk menjadi community worker. Dengan menjalankan tugas dan peran sebagai community worker. Dalam pengelolaan sampah diperlukan partisipasi masyarakat itu sendiri untuk mengatasi kekurangan dari keterbatasan pemerintah tersebut dalam pengelolaan sampah. Mengacu pada pendapat Jim Ife 1995, terjemahan Aribowo (2003: 118-129), pekerja sosial berperan dalam kesehatan lingkungan sebagai : fasilitatif, educational, dan representational.

\section{HASIL DAN PEMBAHASAN}

\section{Bentuk Partisipasi}

Dalam partisipasi pemikiran ini, masyarakat Margaluyu menyalurkan ide-idenya setiap mengikuti kegiatan dalam pengelolaan sampah tidak hanya dalam tahap perencanaan saja melainkan juga tahap pelaksanaan dan evaluasi program. Partisipasi tenaga dilihat dari masyarakat yang ikut serta dilapangan untuk membantu mulai dari mengumpulkan, mengambil sampah hingga mengelola sampah. Selanjutnya partisipasi keahlian atau ketrampilan dilihat dari bentuk usaha guna untuk mendorong aneka ragam usaha yang dilakukan oleh masyarakat Margaluyu. Kemudian partisipasi masyarakat dalam bentuk uang yaitu dari masyarakat Margaluyunya sampai saat ini tidak ada sumbangan uang untuk mengelolanya, sehingga KSM Hanjuang yang sudah berjalan selama 3 tahun mendapatkan sumbangan uang dari pemerintah dan mendapatkan pemasukan dari hasil penjualan pupuk dari sampah yang dikelolanya.

Menurut Sastropoetro, keenam jenis partisipasi seperti yang telah disebutkan diatas merupakan bentuk partisipasi yang bisa diberikan oleh tiap individu. Sebagai contoh adalah saat mengumpulkan sampah, mengelola, memilih sampah, memungkinkan bagi warga untuk peran mereka sebagai keterlibatan dalam kegiatan.
Dengan berbagai jenis partisipasi yang telah disebutkan diatas, maka peneliti menyimpulkan bahwa partisipasi dapat dikelompokkan menjadi 2 jenis, yaitu jenis partisipasi yang diberikan dalam bentuk nyata (memiliki wujud) dan juga jenis partisipasi yang diberikan dalam bentuk tidak nyata (abstrak). Bentuk partisipasi yang nyata misalnya tenaga, uang, ketrampilan. Sedangkan partisipasi tidak nyata adalah hasil pemikiran, partisipasi sosial.

\section{Tingkat Partisipasi Masyarakat}

\section{Tinggi}

- Inisiatif datang dari masyarakat dan dilakukan secara mandiri mulai dari tahapan perencanaan, pelaksanaan hingga pemeliharaan hasil pembangunan. Masyarakat di Lingkungan Margaluyu awalnya tidak memiliki inisiatif sama sekali untuk memulai program pengelolaan sampah, tetapi ada tokoh pemuda di lingkungan itu yang memiliki semangat tinggi untuk peduli lingkungan. Maka dari awal tokoh pemuda ini mulai mengajak akan kebersihan lingkungan, dari situlah KSM Hanjuang dibentuk untuk mulai dari perencanaan hingga program berjalan hingga sekarang.

- Masyarakat tidak hanya ikut merumuskan program, akan tetapi juga menentukan program-program yang akan dilaksanakan.

Sedang

- Masyarakat sudah ikut berpartisipasi, akan tetapi dalam pelaksanaannya masih didominasi golongan tertentu. Masyarakat Margaluyu dalam pelaksanannya masih belum semua ikut berpartisipasi, hanya sebagian masyarakat yang ikut partisipasi dan hanya golongan tertentu saja belum menyeluruh. 
- Masyarakat dapat menyuarakan aspirasinya, akan tetapi masih terbatas pada masalah keseharian.

Rendah

- Masyarakat hanya menyaksikan kegiatan proyek yang dilakukan oleh pemerintah.

- Masyarakat dapat memberikan masukan baik secara langsung atau melalui media massa, akan tetapi hanya sebagai bahan pertimbangan saja.

- Masyarakat masih sangat bergantung kepada dana dari pihak lain sehingga apabila dana berhenti maka kegiatan secara stimulan akan terhenti juga.

\section{SIMPULAN}

1. Partisipasi masyarakat dalam pengelolaan sampah program KSM Hanjuang di Lingkungan Margaluyu Kelurahan Cicurug berjalan sesuai rencana dari tahap perencanaan kegiatan pengelolaan sampah dan tahap pelaksanaan kegiatan pengelolaan sampah dengan diberdayakannya masyarakat dalam pengelolaan sampah program KSM Hanjuang.

2. Partisipasi masyarakat pada tahap perencanaan kegiatan pengelolaan sampah program KSM Hanjuang di Lingkungan Margaluyu Kelurahan Cicurug adalah cukup baik, hal ini ditandai dengan adanya berbagai gagasan atau ide dari warga dalam penentuan keputusan kebijakan yang akan diambil demi kepentingan mewujudkan kesejahteraan hidup dilingkungannya.

3. Partisipasi masyarakat pada tahap pelaksanaan kegiatan pengelolaan sampah program KSM Hanjuang di Lingkungan Margaluyu Kelurahan Cicurug adalah baik. Hal ini dapat dilihat dari kesadaran warga untuk melaksanakan usaha pemilahan sampah, dan dalam pembuatan produk daur ulang dari sampah. Disamping itu berkembangnya swadaya masyarakat yang cukup berhasil, termasuk usaha untuk mengelola sampah dan kebersihan di lingkungannya.

\section{SARAN}

1. Partisipasi masyarakat dalam pengelolaan sampah program KSM Hanjuang di Lingkungan Margaluyu Kelurahan Cicurug pada umumnya perlu dibina dan ditingkatkan dalam rangka mewujudkan lingkungan tempat tinggal yang hijau, bersih dan sehat.

2. Petugas atau aparatur perencana, pelaksana dan pengawasan pengelolaan sampah program KSM Hanjuang di Lingkungan Margaluyu Kelurahan Cicurug diharapkan dapat mengembangkan gagasan atau ide dari warga serta membina tingkat kesadaran partisipasi masyarakat dalam pengelolaan sampah untuk lebih dimantapkan lagi.

3. Partisipasi masyarakat dalam pelaksanaan kegiatan pengelolaan sampah program KSM Hanjuang di Lingkungan Margaluyu Kelurahan Cicurug khususnya dalam kegiatan keterampilan pembuatan produk dari limbah atau sampah terus diusahakan sehingga mampu untuk mengikuti kemajuan tekhnologi pengelolaan sampah dalam rangka mewujudkan kesejahteraan warga masyarakat.

4. Sumber biaya yang selama ini dari swadaya masyarakat, supaya kedepannya dipertimbangkan kembali oleh pemerintah berhubung keterampilan dan kreatifitas dari warga masyarakat dalam berbagai kegiatan pengelolaan sampah mengalami penurunan, sehingga dana dari Pemerintah diharapkan dapat mendukung kegiatan pengelolaan sampah dan kebersihan lingkungan.

\section{DAFTAR PUSTAKA}


Adi, Isbandi Rukminto, 2003. Pemberdayaan, pengembangan masyarakat dan intervensi komunitas (pengantar pada pemikiran dan pendekatan praktis), Jakarta: Lembaga Penerbit FE UI.

Fahrudin, Adi. Ph.D. 2011. Pemberdayaan, Partisipasi, Dan Penguatan Kapasitas Masyarakat. Bandung: Buku Pendidikan - Anggota IKAPI.

Holil Soelaiman, 1980. Partisipasi Sosial dalam Usaha Kesejahteraan Sosial. Bandung.

Huraerah, Abu. 2011. Pengorganisasian dan Pengembangan Masyarakat, Model dan strategi Pembangunan Berbasis Kerakyatan. Bandung: Buku Pendidikan - Anggota IKAPI.

Ife Jim \& Tesoriero. 2008. Alternatif Pengembangan Masyarakat di Era Globalisasi : Community Development.Terjemahan

Manullang, Yakin Nurul, \& Nursyahid. M. Yogyakarta: Pustaka Pelajar.
Notoatmodjo, Soekidjo. 2011. Kesehatan Masyarakat: Ilmu dan Seni. Jakarta: Rineka Cipta.

Sastropoetro, Santoso R.A. 1986. Partsipasi, Komunitas, Persuasi, dan Disiplin Dalam Pembangunan Nasional. Bandung: Alumni.

Wibhawa Budhi, Raharjo. T. Santoso, \& Budiari Meilany. 2010. Dasar-Dasar Pekerjaan Sosial. Bandung:Widya Padjadjaran

Damanhuri Enri \& Tri Padmi. 2010. Diklat Kuliah Pengelolaan Sampah. Progam Studi Teknik Lingkungan.Institut Teknologi Bandung.

Handayani Swi Dewi, Budisulistiorini, Nuraeni Rosie Mya. 2009. Jurnal Presipitasi, UUD Pengelolaan Sampah. Volume 4.Nomor 2.

Profil Kantor Kelurahan Cicurug Kabupaten Majalengka, 2015.

Masyarakat KSM Hanjuang, tahun 2015. 